\title{
Tipologi Filsafat Pendidikan Islam: Kajian Konsep Manusia dan Tujuan Pendidikan Berbasis Filsafat Islam Klasik
}

\author{
M. ABDUL FATTAH SANTOSO ${ }^{1}$, AZAKI KHOIRUDIN² \\ Universitas Muhammadiyah Surakarta ${ }^{1,2}$ \\ e-mail: fattah.sant@gmail.com ${ }^{1,}$ e-mail: azakikhoirudin@gmail.com²
}

\section{ABSTRACT}

Thisstudy discusses typology of I slamic education philosophy derived from educational discourses in the classical I slamic philosophy. While existing construction of the philosophy of Islamic education is still heavily influenced by the Western philosophy, the current study investigates philosophical views of I slamic education from several philosophers in classical Islam. This research focuses on the question of human essence to discover the nature and purpose of Islamic education. The investigation of educational ideas is conducted on the branches of classical Islamic philosophy namely, Peripatetic philosophy (I bn Sina), H ermeneuticPythagorean philosophy (Ikhwan al-Shafa), Illumination philosophy (Suhrawardi), Theosophy-T ranscendent philosophy (M ulla Sadra). This study shows four typologies of Islamic studies philosophy, namely: Rationalism (I bn Sina), ReligiousRationalism (Ikhwan al-Shafa), Enlightenment-Spiritualism (Suhrawardi), and SubstantiveSpiritualism (M ulla Sadra).

Keywords: Education Essence, H uman Essence, and Philosopher of Classical Islam.Philosophy of Islamic Education, and Typology

\section{ABSTRAK}

Artikel ini akan mendiskusikan tentang tipologi filsafat pendidikan Islam yang digali dari aliran filsafat I slam Klasik. Sementara konstruksi filsafat pendidikan Islam yang ada sangat dipengaruhi oleh filsafat Barat, artikel ini menggali pandangan filosofis tentang pendidikan Islam dari pemikiran parafilsuf Islam klasik. Penelitian ini akan memfokuskan pada persoalan hakekat manusia untuk menemukan hakikat dan tujuan pendidikan Islam. Penelusuran gagasan pendidikan dilakukan pada aliran-aliran filsafat Islam klasik yakni, Peripatetik 
(I bnu Sina), H ermeneutikPhitagorean (Ikhwan al-Shafa), I luminasi (Suhrawardi), Teosofi-Transenden (M ullaSadra). H asil penelitian ini menemukan empat tipologi aliran Filsafat Pen didikan Islam: Rasionalisme (I bnu Sina), Rasionalisme-Religius (Ikhwan al-Shafa), Spiritualisme Cahaya (Suhrawardi), dan SpiritualismeSubstantif (M ulla Sadra).

Katakunci: Filsafat Pendidikan Islam, Filsuf Islam K lasik, H akikat M anusia, Tujuan Pendidikan, danT ipologi

\section{PENDAHULUAN}

Kegelisahaan tentang "ketiadaan" Filsafat Pendidikan Islam (FPI) dalam tradisi ilmu pendidikan Islam telah diungkap oleh Abdul M unir Mulkhan. ${ }^{1}$ Hal itu dinyatakan dalam laporan penelitiannya yang berjudul "Jejak Filsafat Islam Dalam Filsafat Pendidikan Islam: Analisis Struktural Fungsional Filsafat Islam dalam Buku Filsafat Pendidikan Islam Terbitan Dalam Negeri dan Terjemahan" oleh Lembaga Penelitian dan Pengabdian Kepada M asyarakat UIN Sunan Kalijaga tahun 2013. M enurutnya selama ini praktik tarbiyah cenderung mengadopsi teori dari Filsafat Barat. Padahal tradisi tarbiyah telah tumbuh sejak sebelum manusia mengenal pedagogy, education, learning, dan teaching. Seharusnya Filsafat Pendidikan Islam disusun sebagai terapan Filsafat Islam di bidang pendidikan sebagaimana George R. Knight membangun filsafat pendidikan (Barat) disusun dari para filsuf Barat. ${ }^{2}$ Hasil penelitian tersebut, menyatakan bahwa buku-buku Filsafat Pendidikan Islam di Indonesia tidak dibangun dari Filsafat Islam.

Kajian tipologi Filsafat Pendidikan Islam yang berpijak pada pandangan filsuf Islam telah dimulai oleh Muhammad Jawwad Ridla dalam bukunya yang berjudul Tiga Aliran Utama Teori Pendidikan Islam (Perspektif Sosiologis-Filosofis). M enurutnya, setidaknya ada tiga tipologi/aliran utama dalam filsafat pendidikan Islam, yaitu: (1) aliran Agamis-Konservatif, (2) aliran Religius-Rasional, dan (3) aliran Pragmatis-Instrumental. ${ }^{3}$ Menurut M unir M ulkhan, hasil kajian Jaw wad Ridla telah memberikan sumbangan penting pemikiran pendidikan Islam yang berpijak pada filsafat Islam, ketika pemikiran dan praktik pendidikan Islam kebanyakan dipandu filsafat Barat. Walaupun Jawwad Ridla belum berhasil menjelaskan secara memadai mengapa Al-Ghazali disebut konservatif, apakah karena Al-Ghazali adalah sosok yang anti-filsafat? ${ }^{4}$ Kalau demikian alasannya, mengapa seorang yang menolak Filsafat dimasukkan dalam Filsafat pendidikan Islam? Mengapa Ikhwan al-Shafa disebut religious-rasional dan Ibnu Khaldun disebut pragmatis? Tidak cukup di situ, mengapa tiga aliran tersebut dipilih 
sebagai aliran utama pemikiran pendidikan Islam? M engapa Jawwad Ridla tidak menggunakan aliran aliran Filsafat Islam klasik, sebagaimana diperkenalkan Syeed Hossein Nasr, ${ }^{5}$ yaitu M adzhab Peripatetik (M asya'i), Madhab Hermeneutik-Phitagorean (Ismaili), Madzhab Iluminasi (Isyraqi), dan Madzhab Teosofi-Transenden (al-Hikmah al-M utaaliyah)?

Karena itu, penelitian ini menjadi penting dalam rangka menggali filsafat pendidikan Islam dari aliran utama filsafat Islam klasik sebagaimana disebut di atas, yaitu: M asya'iyah (Peripatetisme) dengan tokoh Ibnu Sina, Ismaili (hermenetik-Phitagorean) oleh Ikhwan al-Shafa, Isyraqiyah (iluminasionisme) dengan tokohnya Suhrawardi, dan aliran Hikmah M uta'aliyah (Teosofi-Transenden) dengan tokohnya Mulla Sadra. Penelitian ini membatasi pada persoalan tentang hakikat manusia dan kemungkinannya ke arah rumusan pendidikan berbasis filsafat Islam. Hakekat manusia diperlukan karena subjek didik (masukan mentah) dalam pendidikan adalah manusia. Supaya tidak salah ke mana arah tujuan pendidikan, maka diperlukan pengetahuan tentang hakekat manusia.

Untuk itu, penelitian ini berangkat dari asumsi dasar bahwa Filsafat secara struktural-fungsional ialah (the body of knowledge) sumber dari IImu. ${ }^{6}$ Maka dari itu, Teknologi dan IImu (teori) Pendidikan Islam berarti bersumber dari Filsafat Islam. Bagi George R. Knight, filsafat pendidikan Islam adalah turunan dari Filsafat Islam. ${ }^{7}$ Sebagaimana Al-Syaibany bahwa Filsafat pendidikan tidak lain ialah pelaksanaan falsafah dalam bidang pendidikan. ${ }^{18}$ Dengan kata lain, Filsafat Pendidikan Islam adalah pelaksanaan metodologi Filsafat Islam dalam membicarakan persoalan dan isuisu bidang pendidikan terutama untuk mencari konsep tentang arah \& tujuan pendidikan. Atas dasar itu, hasil kajian ini diharapkan berguna bagi pengembangan ilmu (teori) pendidikan Islam sebagai panduan praktik tarbiyah (pendidikan Islam) di dunia Islam, khususnya Indonesia.

\section{KAJIAN FILSAFAT PENDIDIKAN ISLAM: PENDEKATAN TIPOLOGI}

Secara umum, tipologi aliran filsafat pendidikan Islam tidak bisa terlepas dari pola pemikiran yang dikembangkan oleh para pemikirnya. Karya-karya pendidikan Islam yang sebagiannya menyinggung filsafat pendidikan, yang berbau pemikiran, dan atau yang berlabel "Filsafat Pendidikan Islam" mulai berkembang sejak tahun 1980-an, seperti Prinsip Dasar Konsepsi Pendidikan Islam karya Syahminan Zaini (1986), Filsafat Pendidikan Islam karya 
M. Arifin (1987), Filsafat Pendidikan Islam oleh Tim Proyek Dibinpertais (1984), karya-karya Hasan Langgulung, seperti Asas-Asas Pendidikan Islam (1988), Pendidikan Islam Menghadapi Abad ke-21 (1988), Manusia dan Pendidikan (1986), dan Beberapa Pemikiran tentang Pendidikan Islam (1980). ${ }^{9}$

Buku-buku yang khusus membahas tentang "Filsafat Pendidikan IsIam" pada tahun 1990-an hanya ditemukan 2 buku yang khusus membahas filsafat pendidikan Islam, yaitu: Filsafat Pendidikan Islam karya Jalaluddin \& Usman Said (1994), dan Filsafat Pendidikan Islam karya Abuddin Nata (1997). Selebihnya sekedar bersifat pengantar, seperti Paradigma Intelektual Muslim Pengantar Filsafat Pendidikan Islam dan Dakwah karya Abdul Munir Mulkhan (1993). Kalaupun ada yang sekedar mengandung unsur pemikiran (filsafat), seperti: Pemikiran Pendidikan Islam (Kajian Filosofis dan Kerangka Dasar Operasionalnya) karya M uhaimin \& Abdul Mudjib (1993), Konsep Pendidikan Islam, Sebuah Telaah Komponen Dasar Kurikulum, karya Muhaimin (1993), Kreativitas dan Pendidikan Islam Analisis Psikologi dan Falsafah karya Hasan Langgulung (1990), Ilmu Pendidikan dalam Perspektif Islam karya A. Tafsir (1992), Visi Pembaharuan Pendidikan Islam karya A. Malik Fadjar (1998), Pendidikan Islam Tradisi dan Modernisasi Menuju Millenium Baru karya Azyumardi Azra (1999), Memberdayakan Sistem Pendidikan Islam karya Mastuhu (1999), dan lain-lain. Di samping itu, terdapat buku-buku pemikiran para tokoh pendidikan Islam, misalnya buku berjudul Pemikiran Pendidikan Islam Kajian Tokoh Klasik dan Kontemporer yang ditulis oleh dosen-dosen Fakultas Tarbiyah IAIN Semarang (1999); buku Pemikiran Para Tokoh Pendidikan Islam (Seri Kajian Filsafat Pendidikan Islam) oleh Abuddin Nata (2000), buku-buku Filsafat Pendidikan Islam karya Jalaluddin, Abuddin Nata; dan buku Hasan Langgulung, Manusia dan Pendidikan (1986), juga memuat tokoh-tokoh pendidikan Islam. Upaya penerjemahan buku-buku berbahasa asing juga dilakukan untuk penggalian pemikiran tokoh-tokoh pendidikan Islam, antara lain buku Arabic Contributions to Educational Thought oleh Tedd D. Beavers (2001), dan lain-lain. ${ }^{10}$

Tesis M unir M ulkhan yang menyatakan bahwa Filsafat Pendidikan Islam (Tarbiyah) merupakan penerapan Filsafat Islam di bidang pendidikan Islam sebagaimana Filsafat Pendidikan (Barat) disusun dari Filsuf Barat, mendorong penelitian ini. ${ }^{11}$ Beberapa buku tentang Filsafat Pendidikan Islam kenyataanya telah menggunakan berbagai aliran filsafat pendidikan 
(Barat) untuk menjelaskan Filsafat Pendidikan Islam. Buku-buku tersebut telah ditulis antara lain: Zuhairini dkk, ${ }^{12}$ M . A rifin, ${ }^{13} \mathrm{Abd}$. Rachman Assegaf, ${ }^{14}$ meskipun berjudul Filsafat Pendidikan Islam, namun didalamnya malah membahas aliran-aliran Filsafat Pendidikan (Barat) seperti: Perenialisme, ${ }^{15}$ Esensialisme, ${ }^{16}$ Progresivisme ${ }^{17}$ dan Rekonstruksionisme. ${ }^{18}$ Zuhairini dkk, tim yang dibentuk Kementerian Agama, selain menggunakan Filsafat Barat, buku ini justru mengutip pernyataan Imam Barnadib dua corak, yaitu filsafat tradisional dan filsafat kritis." Ironinya "aliran filsafat dalam Islam" dan "sistem filsafat dalam Islam" tidak dibahas secara detail. M. Arifin dalam Filsafat Pendidikan Islam, juga tidak membahas pandangan Filsuf Muslim, justru dimulai membahas pengertian filsafat pendidikan menurut John Dewey, Thomson, Van Cleve Morris, dan Brubacher. Nasib serupa terlihat dalam buku Omar Mohammad Al-Toumy Al-Syaibani, berjudul Falsafah Tarbiyyah al-Isl-amiyah. Baginya buku Filsafat Pendidikan di negaranegara Arab dan negara Islam, mengambil pemikiran Barat seperti Plato, Aristoteles, Thomas Hobbes, John Locke, Jean Jack Rousseau, John Dewey, tanpa membahas pemikiran ahli Arab. ${ }^{19}$ Yang paling kontemporer adalah Abd. Rachman Assegaf mencoba merumuskan Filsafat Pendidikan Islam berbasis paradigma keilmuan integrasi-interkoneksi Amin Abdullah. Assegaf mencoba menghadirkan khasanah Filsafat Pendidikan Islam alToumy al-Syaibani dan Barat John Dewey, namun belum memberikan "titik temu" atau tawaran alternatif dari Filsafat Pendidikan Islam baru.

Kajian Muhaimin menyatakan bahwa selama ini pemikiran pendidikan Islam dikategorikan ke dalam dua kelompok utama, yaitu aliran filsafat kritis, yakni madzhab pemikiran yang berkemajuan atau progresif dalam pendidikannya, dan madzhab pemikiran filsafat pendidikan yangbersifat tradisional. ${ }^{20}$ Khususnya di Indonesia, kajian tipologi Filsafat Pendidikan Islam telah dilakukan oleh Muhamin dalam sebuah disertasi. Hasil kajian menunjukkan bahwa pemikiran (filsafat) pendidikan Islam mengarah pada lima tipologi, yaitu: Perenial-Esensialis Salafi, ${ }^{21}$ Perenial-Esensialis M azhabi, ${ }^{22}$ M odernis, ${ }^{23}$ Perenial-Esensialis Kontekstual-Falsifikatif, ${ }^{24}$ dan Rekonstruksi Sosial. ${ }^{25}$ Dari kelima tipologi tersebut, terlihat kecenderungan pemikiran Filsafat Pendidikan Islam di Indonesia nampak bervariasi. Ada yang mengarah pada tipologi perenial-esensialis salafi yang tampak pada karya Jalaluddin \& Usman Said, perenial-esensialis mazhabi pada karya Abuddin Nata, dan tipologi modernis pada karya Arifin dan Ahmad Tafsir. M eskipun tipologi pemikiran mereka berbeda-beda, tetapi memiliki karakteristik yang 
hampir sama, yakni kurangnya kritisisme yang memadai. ${ }^{26}$ Mastuhu menawarkan tipologi perenial-esensialis kontekstual-falsifikatif, serta Azyumardi Azra dan Noeng Muhadjir cenderung menawarkan tipologi rekonstruksi sosial. ${ }^{27}$

Dalam melakukan tipologisasi Filsafat Pendidikan Islam di atas, Muhaimin terjebak pada madzhab-madzhab pemikiran Islam di Indonesia. M uhaimin membawa filsafat pendidikan ke pada madzhab pemikiran Islam di Indonesia seperti salafi dan modernis yang bersifat ideologis. Selain itu Muhaimin juga masih menggunakan filsafat pendidikan (Barat) untuk menjelaskan pendidikan Islam, sehingga di sini masih menyisakan pekerjaan rumah untuk merumuskan Flsafat Pendidikan Islam berbasis Filsafat Islam.

Kajian tipologi filsafat pendidikan Islam yang dikonstruksi dari pemikiran filsuf Islam telah dimulai oleh Muhammad Jawwad Ridla dalam bukunya yang berjudul Tiga Aliran Utama Teori Pendidikan Islam (Perspektif Sosiologis-Filosofis). Ada tiga aliran utama dalam filsafat pendidikan Islam, yaitu: (1) Agamis-Konservatif, (2) Religius-Rasional, dan (3) PragmatisInstrumental, ${ }^{28}$ Pertama, Agamis-Konservatif fokus pada persoalan pendidikan yang cenderung murni dalam menyikapi urusan keagamaan. M ereka memaknai ilmu dalam pemahaman sempit, mencakup ilmu-ilmu yang dibutuhkan saat di dunia, yang membawa manfaat untuk kehidupan di akhirat kelak. Materi pembelajaran harus dimulai dari Al-Qur'an. Segala sesuatu yang berhubungan dengan al-Quran harus dipelajari dan dipahami, mulai dari menghafal hingga tafsirnya. Menurut Jawwad, tokoh utama pendidikan ini adalah Imam al-Ghazali, selain itu Jawwad juga menyebut Nasiruddin at-Thusi, Ibn Jama'ah, Ibn Hajar al-Haitami dan al-Qabisi. Kedua, Religius-Rasional. Golongan ini cenderung bersikap rasional dalam menghadapi persolan pendidikan. Menurut Jawwad Ridla, Ikhwan al-Shafa merupakan representasi dari aliran ini, yang juga memasukkan al-Farabi, Ibn Sina, dan Ibn Maskawaih sebagai golongan aliran ini. Mereka juga dijuluki sebagai 'pemburu hikmah', karena pergumulan mereka dalam berbagai rasionalitas Yunani. Ketiga, Ibn Khaldun, menurut Jawwad Ridla adalah satu-satunya tokoh dalam aliran Pragmatis-Instrumental. Pemikirannya dalam bidang pendidikan terkesan pragmatis dan cenderung aplikatifpraktis. Manusia mampu bereksperimen dengan akal keduanya, selanjutnya mampu mengkonseptualkan dalam realitas empiris dan non-empiris melalui akal tertingginya. 
Uraian buku tersebut menurut Abdul Munir Mulkhan dinilai kurang praktis jika dibanding buku sejenis yang dipakai di kalangan perguruan umum membuat buku ini belum banyak memberikan pengaruh yang berarti. ${ }^{29}$ M eskipun demikian, Jawwad Ridla telah memberikan sumbangan penting pemikiran filosofis bagi pendidikan yang berpijak pada filsafat Islam. Hal yang perlu diperhatikan, bahwa Jawwad ridla belum menjelaskan secara memadai alasannya mengapa Ikhwan al-Shafa disebut rasional, Al-Ghazali disebut konservatif, dan Ibnu Khaldun disebut pragmatis? Mengapa Al-Ghazali yang memerangi Filsafat dimasukkan dalam Tiga Aliran Pemikiran pendidikan Islam? Bagaimana mungkin seorang yang tidak menerima Filsafat memiliki gagasan filosofis untuk menjelaskan pendidikan Islam ${ }^{30}$ Jawwad Ridla membangun tiga aliran utama pendidikan Islam berdasarkan pada historis-sosiologis. Artinya Jawwad Ridla membawa pemikiran pendidikan Islam tunduk pada logika sejarah.

Selain itu, Jawwad Ridla belum menjelaskan secara fungsional-filosofis, bahwa Filsafat Islam digunakan untuk menjelaskan pemikiran pendidikan. Jawwad Ridla hanya memilih tiga tokoh (Filsuf) yang mempunyai "konsepkonsep" tentang pendidikan Islam, bukan menjelaskan Filsafat Pendidikan Islam sebagai bagian dari gagasan Filsafat Islam. Tawaran gagasan Jawwad Ridla lebih tepat disebut sebagai ilmu (pemikiran) pendidikan Islam, daripada Filsafat pendidikan Islam. Di sinilah pentingnya menggali gagasan Filsafat Pendidikan Islam dari tradisi besar Filsafat Islam klasik yang telah ada dan sangat kaya akan gagasan filosofis. Jika Jawwad Ridla menjelaskan tipologi pemikiran pendidikan Islam dengan memahami posisi dan fungsi ilmu, maka pada penelitian ini akan menjelaskan filsafat pendidikan Islam dengan mencari konsep manusia dari para filsuf klasik untuk mendapatkan tujuan pendidikan Islam.

\section{MENCARI TIPOLOGI BARU FILSAFAT PENDIDIKAN ISLAM BERBASIS FILSAFAT ISLAM}

Sebelum memetakan tipologi, diperlukan terlebih dahulu melakukan pemetaan terhadap gagasan dari Filsafat Islam. Secara garis besar gagasan Filsafat Islam bisa dibedakan dalam empat sudut pandang, yaitu: M asya'i (peripatetik), isyraq (ilmuninasi), irfan (gnonis), dan kalam (teologi). Peripatetis (masyaiyah) berbasis deduksi, logika, dan spekulasi rasional, mengadopsi Filsafat Yunani, sintesis Aristoteles dan Plato. Sementara Irfan (gnosis atau Makrifat) berbasis intuisi mistik supra-rasional, melalui suatu 
penyucian batin (sufisme). Pemikiran irfani tumbuh dan berkembang dalam Hikmah M uta'aliyah (Teosofi Transenden) sebagai sintesis Filsafat Islam. ${ }^{31}$ Filsafat Islam mencapai puncaknya di tangan M ulla Sadra karena berhasil menggabungkan unsur terbaik dari filsafat Peripatetik (terutama Ibnu Sina) dan filsafat Iluminasionis, dan kemudian memperkaya-nya dengan fisafat Wujudiah sufi (khususnya) Ibnu Arabi, sehingga melahirkan ajaran filsafat baru. Suhrawardi (hikmat al-isyraq) dan semua filosof Islam sesudahnya memandang hikmah sebagai al-hikmah al-ilahiyyah (secara harfiah, kebijaksanaan ilahi atau teosofi) yang harus direalisasikan dalam sosok utuh manusia dan bukan hanya secara mental. Sebelum munculnya rasionalisme Aristotelian, dan mengidentifikasi hikmah dengan pelepasan diri dari tubuh dan pendakian ke dunia cahaya, sebagaimana halnya Plato. Dia menandakan bahwa tingkat dan derajat tertinggi hikmah mensyaratkan kesempurnaan daya rasional dan kesucian jiwa." ${ }^{32}$

Perbedaan mendasar antara Ibnu Sina dan Mulla Sadra, terletak di bidang psikologi. Bagi Ibnu Sina, psikologi merupakan cabang filsafat alam (thabi'iyyat) yanglebih membahas fakultas-fakultas jiwa. Sebaliknya, Mulla Sadra memandang psikologi sebagai cabang metafisika (ilahiyyah) dimana fakultas jiwa lebih secara bathiniyah daripada lahiriyah. ${ }^{33}$ Adapun perbedaan Mulla Sadra dengan Suhrawardi terletak pada hakikat realitas. Bagi Sadra, hakikat realitas adalah pada eksistensi (prinsipalitas eksistensi/ ashalat al-wujud), sementara Suhrawardi mempercayai prinsipalitas esensi (ashalat al-wujud). Perbedaan mendasar ini disebut oleh Corbin sebagai revolusi filsafat Islam. Akhirnya dalam filsafatnya, Sadra meninggalkan gagasan Suhrawardi dan mengikuti doktrin hilomorfisme ${ }^{34}$ Ibnu Sina. Lalu, Sadra menerjemahkan doktrin tersebut ke dalam kerangka prinsip gerakan substansial (al-harakah al-jauhariyyah) yang menjadi salah satu dasar ajaran teosofi transenden. ${ }^{35}$

Meskipun Suhrawardi dan Mulla Sadra berbeda dalam memandang metafisika atau hakikat realitas, tetapi memiliki titik temu pada epistemologi, yakni berhasil mengawinkan pengetahuan rasional dan pengetahuan intuitif. Jika Suhrawardi memandang bahwa hakikat realitas adalah pada esensinya, maka M ulla sadra berpandangan wujud sebagai realitas. Walaupun demikian, orientasi kedua filsafat ini adalah perenialisme atau spiritualisme. Menurut Hossein Nasr, teosofi transenden Mulla Sadra menjadi salah satu ekspresi filsafat akhir dalam sejarah manusia, yakni filsafat perennial sekaligus universal, shopia perennis (al-hikmah al-khalidah). ${ }^{36}$ 
Selanjutnya, menurut Abdul Munir Mulkhan dengan merujuk karya Seyyed Hossein Nasr dan Oliver Leaman Ensiklopedi Tematik Filsafat Islam, secara umum filsafat Islam terbagi menjadi dua aliran: Pertama, Peripatetik yang cenderung rasionalisme Yunani. Kedua, Iluminasionis atau TeosofiTransendental yang lebih menekankan spiritualisme. Dua aliran tersebut adalah pembagian secara global, namun senada dengan pembagian Syeed Hossein Nasr dalam bukunya Islam Tradisi. ${ }^{37}$ Nasr membagi aliran Filsafat Islam menjadi empat madzhab, yakni M asya'i (Peripatetik) dengan tokoh Ibnu Sina, Hermetik-Pitagorean (Ismaili) oleh Ikhwan al-Shafa, Isyraqi (iluminasionisme) dengan tokohnya Suhrawardi, dan aliran al-Hikmah alMutaaliyah (Teosofi Transendental) dengan tokohnya Mulla Sadra. ${ }^{38}$ Dua aliran pertama dipengaruhi oleh tradisi filsafat Yunani Kuno (NeoPlatonisme dan Neo-Pitagorean-isme), dan dua aliran terakhir dipengaruhi tradisi yang sama dan tradisi filsafat perenial (keabadian) lainnya, terutama Persia Kuno. Wajar jika kedua aliran pertama yakni Peripatetik dan Hermenetik-Phitagorean lebih bernuansa "Rasionalisme". Hanya saja Rasionalisme Peripatetik lebih menonjol karena dipengaruhi logika Yunani, sedangkan Hermenetik-Pitagorean selain Rasionalisme juga mengedepankan aspek religiusitas, maka dengan ini bisa penulis menyebutnya dengan "Rasionalisme-Religius". Berbeda dengan dua aliran terahir yakni Iluminasi dan Teosofi-Transenden, keduanya cenderung bercorak Spiritualisme, hanya saja Ilmuminasi menggunakan konsep Spiritualisme-Cahaya, sedangkan Teosofi-Transenden lebih pada Spiritualisme-Substantif.

Empat madzhab di atas yang akan menjadi pijakan menjelaskan tipologi filsafat pendidikan Islam klasik. Karena sejatinya filsafat pendidikan Islam ialah teori pendidikan yang berpijak pada filsafat Islam. Menurut Abd. Rachman Assegaf, pemikiran filosofis menjadi dasar dan sumber pemikiran pendidikan. ${ }^{39}$ Jadi, pemikiran pendidikan tidak memisahkan diri dari landasan pemikiran filsafat, karena membentuk pemikiran pendidikan. Sebagaimana dinyatakan George R. Knight filsafat adalah kerangka dasar yang melandasi praktik pendidikan. ${ }^{40}$ Selain itu, berbicara tentang filsafat, termasuk filsafat Islam, objek kajiannya - mengikuti Francois Bacon—akan mencakup tiga kategori: Tuhan, alam, dan manusia. ${ }^{41}$

Karena itu, berbicara filsafat pendidikan tidak lepas dari konsep manusia. Sebab, sejatinya pendidikan adalah usaha dan proses "memanusiakan manusia". Bagian ini akan menggali Filsafat Pendidikan Islam dari aliran utama Filsafat Islam klasik sebagaimana pembagian penggalian gagasan 
filsafat pendidikan Islam, akan dimulai dari penelusuran terhadap hakikat manusia sebagai dasar merumuskan tujuan filosofis pendidikan dari masing-masing aliran. Dengan berpijak pada pandangan filosofis dari empat madzhab utama Filsafat Islam Klasik, yaitu: M asya'iyah (Peripatetik) Ibnu Sina, Hermenetik-Phitagorean Ikhwan al-Shafa, Isyraqiyah (Iluminasi) Suhrawardi, dan aliran Hikmah Muta'aliyah (Teosofi-Transenden) Mulla Sadra, tulisan ini fokus pada kajian konsep hakikat manusia dan tujuan pendidikan untuk menggali kecenderungan tipologi filsafat pendidikan Islam, maka ditemukan lima aliran, yakni: Rasionalisme, RasionalismeReligius, Spiritualisme-Cahaya, Spiritualisme-Substantif.

\section{MADZHAB PERIPATETIK DAN FILSAFAT PENDIDIKAN ISLAM RASIONALISME}

Dalam menjelaskan Filsafat Pendidikan Islam (FPI) aliran Rasionalisme, penulis mengelaborasi dengan konsep Filsafat Islam (FI) Madzhab Peripatetik (masya'iyyah) Ibnu Sina. Filsafat Islam Peripatetik berkembang antara abad 3H/9M s.d. 6H/12M di wilayah Timur dunia Islam dengan pusatnya Baghdad, dan secara khusus di wilayah Barat (Spanyol) pada abad 6H/12M. Secara konseptual, FI Peripatetik merupakan sintesis pemikiran Plato, Aristoteles, Pitagoras dan kaum Stoik (disebut Neoplatonisme) dalam wacana pandangan-dunia Islam. Pengaruh Plato tampak pada etika dan politik, Aristoteles pada logika dan fisika, Pitagoras pada metafisika, dan kaum Stoik pada kosmologi. FI Peripatetik dirintis oleh al-Kindi (w. 873) dan dikembangkan oleh ar-Razi (w. 925), al-Farabi (w. 950), Ibnu M iskawaih (w. 1030), Ibnu Sina (w. 1036), Ibnu Bajjah (w. 1138), Ibnu Thufail (w. 1185), Ibnu Rusyd (w. 1198). Tiga filsuf terakhir mengembangkan Fl di wilayah Barat (Spanyol).

Untuk mendapatkan gagasan filosofis tentang pendidikan menurut filsafat Islam aliran Peripatetik, maka perlu digali terlebih dahulu hakikat manusia menurut Ibnu Sina. Adapun pandangan Ibnu Sina tentang hakikat manusia dapat dilihat bagaimana konsepnya tentang jiwa manusia. Ibnu Sina mengikuti pembagian jiwa yang telah disusun oleh al-Kindi dan alFarabi. la membagi potensi jiwa (nafs) ke dalam tiga bagian. Pertama, nafs nabati (jiwa tumbuhan), yaitu kesempurnaan utama bagi kebutuhan fisik alami dari aspek reproduksi, pertumbuhan, dan makan. Makanan merupakan suatu fisik yang menyerupai sifat fisik yang dikatakan sebagai makanannya. Di sana ia bertambah menurut kadar yang terurai darinya, 
bisa lebih banyak atau lebih sedikit. Kedua, nafs hewani (jiwa tumbuhan), yaitu kesempurnaan utama bagi fisik alami mekanik dari aspek persepsi terhadap partikular-partikular dan bergerak atas kehendak sendiri. Ketiga, nafs insani (jiwa rasional), yaitu kesempurnaan utama bagi fisik alami mekanik dari aspek melakukan aktivitas-aktivitas yang ada atas pilihan menurut pertimbangan dan kesimpulan pikiran, serta dari aspek persepsi terhadap hal-hal universal. Dari sini dapat didapatkan bahwa hakikat manusia menurut Ibnu Sina adalah Jiwa rasionalnya. ${ }^{42}$ Jiwa rasional memiliki dua daya, yaitu "practical faculty" dan "theoritical faculty". Jiwa rasional kelebihannya terletak pada fungsi akal sebagai "the first intellegency of rational and rational deduction and in so far as it perceives universe". ${ }^{43}$

Jiwa berfungsi menjadi sebab hidup, penggerak, dan pengendali tubuh. Bila tubuh mengalami perubahan dan penyusutan (sesuai dengan biologi modern tentang pergantian sel), maka tidak demikian halnya jiwa. Sifat manusia bergantung pada jiwa mana dari ketiga macam jiwa yang paling berpengaruh pada dirinya. Jiwa manusia akan bersifat seperti malaikat bila jiwa berpikirnya dapat mengaktual sampai ke taraf akal mustafad dan-bersama akal praktis- berpengaruh besar pada jiwa binatang dan tumbuhan. Namun, bila pada dirinya berkuasa jiwa tumbuhan dan binatang, maka sifatnya hanya menyerupai binatang saja. Akal praktis mengendalikan jiwa tumbuhan dan binatang agar akal teoritis mampu mengaktual secara sempurna. Berdasarkan teori jiwanya ini, karena hakikat manusia adalah jiwa rasionalnya, maka hakekat pendidikan adalah aktualisasi dan penyempurnaan potensi akal manusia, baik akal praktisnya maupun akal teoritisnya. Pendidikan rasionalisme merupakan terapan aktualisasi akal teoritis, sementara pendidikan akhlak merupakan terapan aktualisasi akal praktis dan teoritis. Pendidikan dilaksanakan secara moderasi dengan memperhatikan perkembangan usia dan jiwa anak. ${ }^{44}$

Proses pendidikan dimulai dengan peran orang tua sebagai guru pertama, lalu peran guru sekolah, dan ditutup peran akal aktifdiidentifikasikan dengan malaikat-sebagai guru pada hirarkhi teratas yang mencerahkan jiwa. Selain itu, keluarga dan sekolah saling melengkapi dalam mempromosikan tujuan pendidikan dasar, yaitu menguatkan iman, membina akhlak dan kesehatan, serta mengajarkan literasi, berfikir benar, dan keterampilan. Guru harus mempunyai pengaruh besar terhadap pikiran dan akhlak siswa. Adapun peranan sekolah, selain transmisi pengetahuan, 
adalah memberi pengalaman hidup individual dan sosial. Pengalaman hidup individual berupa mengontrol emosi. Siswa tidak dikondisikan untuk marah, takut, sedih, dan sulit tidur, namun diberi yang menye-nangkan hati dan membangkitkan selera. Sebagai implikasinya, pikiran terbiasa dengan emosi positif, kebiasaan yang baik dikembangkan, dan badan pun memperoleh manfaat dari kondisi tersebut. Adapun pengalaman hidup sosial berupa hidup bersama, menambah kawan, saling belajar, saling memotivasi, saling berkompetisi secara sehat, saling berdiskusi yang meningkatkan pemahaman, dan saling menguat-kan nilai-nilai. Dengan demikian, pendidikan dilaksanakan secara moderasi dengan memperhatikan perkembangan usia dan jiwa peserta didik.

\section{MADZHAB HERMENETIK-PYTHAGOREAN DAN FILSAFAT PENDIDIKAN ISLAM RASIONALISME -RELIGIUS}

Filsafat Islam Madzhab Hermenetik-Pythagorean berkembang pada abad ke-4 H/ke-10 M sebagai aliran alternatif di tengah perkembangan aliran Peripatetik. Lahir di Irak, aliran ini berkembang di Persia, Yaman dan akhirnya India (rumah intelektual terakhirnya). Aliran ini disebut juga aliran Ismailiyah dengan para tokohnya: Abu Hatim ar-Razi, Abu Sulaiman asSijis-tani, Hamiduddin al-Kirmani, dan Nasir Khusrau. Termasuk dalam aliran ini para filsuf kelompok Ikhwan al-Shafa. Ikhwan al-Shafa adalah nama kelompok filsuf muslim yang berarti 'saudara-saudara (yang mementingkan) kesucian (batin/jiwa)', didirikan dan ber-kembang di Basrah pada abad ke-4 H/ke-10 M (al-Faruqi mencatat 313-363 H/927-975M, sementara at-Tauhidi-dengan berpijak pada data internal risalah mereka mencatat 347-373 H/958-983 M ). Kelompok ini merahasiakan identitas dan aktivitas mereka, diperkirakan untuk keselamatan diri mereka, baik dari pihak yang mencurigai dan memusuhi filsafat maupun dari pihak penguasa yang secara politik berseberangan (penguasa yang Sunni dan Ikhwan al-Shafa yang Syiah Ismailiyah). Ikhwan al-Shafa memperoleh dukungan dari Dinasti Fathimiyah di Mesir pada saat mulai memudarnya pamor kekhalifahan Abbasiyah, dan di antara pemukanya yang dapat teridentifikasi: Abu Sulaiman al-Bisti/al-Maqdisi, Abu al-Hasan az-Zanjani, Abu Ahmad alMihrajani, Abu al-Hasan al-Aufi, dan Zaid bin Rifa'ah.

Secara konseptual, Ikhwan al-Shafa lebih dipengaruhi tradisi Neopitagoreanisme daripada Neoplatonisme, karena karakter religius dan mistis, kecenderungan esoteris, dan obsesi matematika sebagai jalan pasti menuju 
kebenaran yang terdapat pada tradisi pertama, sangat sesuai dengan keyakinan kaum Ismailiyah. Ikhwan al-Shafa terbagi dalam kelompokkelompok yang mengadakan pertemuan secara berkala untuk mengkaji ilmu, filsafat dan agama. Kajian mereka mewariskan karya ensiklopedi tentang ilmu dan filsafat, dikenal dengan Rasâ'il Ikhwan ash-Shafa terdiri dari 51/52/53 risalah, yang berisi aneka pemikiran filsafat, matematika, fisika, metafisika, dan politik yang ditulis dengan kemasan populer sehingga tersebar ke seluruh wilayah dunia Islam waktu itu, Timur dan Barat (Andalusia/Spanyol). ${ }^{45}$

Ikhwan al-Shafa memang sangat terkenal dalam bidang science. Bagi Ikhwan al-Shafa permulaan filsafat adalah kecintaan terhadap sains. Filsafat sains ada 4 jenis, yaitu: M atematika, Logika, Filsafat Alam dan M etafisika. Sebaiknya manusia mempelajari terlebih dahulu matematika dan bilangan, sebelum mengkaji cabang-cabang keilmuan lain yang lebih tinggi seperti fisika, logika, dam Ketuhanan. Ikhwan al-Shafa memegang keyakinan Pythagorean bahwa sifat dasar hal-hal yang diciptakan adalah sesuai dengan sifat dasar bilangan. Bagi Ikhwan al-Shafa seseorang dapat belajar tentang keEsaan Tuhan dengan mengetahui hal-hal yang berkenaan dengan angka-angka. ${ }^{46}$ Mereka menolak gagasan Pythagorean tentang "perpindahan jiwa" (reinkarnasi), dan lebih berpegang pada gagasan penyucian yang tercapai dalam satu kali kehidupan di bumi yang dapat memasukkan manusia ke surga.

Ikhwan al-Shafa secara imajinatif-filosofis mengajukan teori tentang "manusia" dan kebutuhan-kebutuhan perkembangannya yang bersifat pedagogis. M anusia terdiri dari jiwa dan jasad yang hidup di dunia. Ikhwan al-Shafa mengakui prinsip dasar material bagi pengetahuan manusia. Hal ini menegaskan pentingnya indera bagi penataan relasi makhluk hidup dengan lingkungan eksternalnya. M ereka membedakan antara indera (alhawas) dan daya indera (al-quwwah al-hassah). Yang pertama adalah "tempat" bagi yang kedua. Indera adalah sarana jasadiyah yang berjumlah lima (mata, telinga, lidah, hidung dan tangan), sedangkan daya inderawi adalah daya jiwa yang secara spesifik dimiliki oleh masing-masing organ tubuh. ${ }^{47}$

Seperti para filsuf Peripatetik, Ikhwan al-Shafa memandang manusia terdiri dari dua unsur, yaitu jiwa yang bersifat immateri, dan tubuh yang merupakan campuran dari tanah, air, udara dan api. Dari dua unsur itu, hakekat manusia terletak pada jiwanya. Jiwa manusia adalah substansi 
yang memiliki lima potensi, yaitu: spiritual, melangit, bercahaya, hidup, dan memiliki pengetahuan. Masuknya jiwa ke dalam tubuh merupakan hukuman karena jiwa melakukan pelanggaran (kasus Adam dan Hawa yang diusir dari surga/alam rohani). Dengan hukuman itu, jiwa yang semula memiliki pengetahuan yang banyak secara aktual, setelah memasuki tubuh, menjadi lupa sama sekali dengan pengetahuannya, sehingga pengetahuan berada di dalam jiwa secara potensial saja. Secara berangsur-angsur manusia dapat memiliki kembali pengetahuan secara aktual dengan bantuan panca indera, akal dan hati sebagai alat jiwa. ${ }^{48}$

Dengan demikian, hakikat pendidikan Ikhwan al-Shafa adalah aktualisasi potensi-potensi jiwa (yang berjumlah lima tersebut), menyempurnakan dan menyiapkannya untuk kehidupan abadi. Dengan demikian, pendidikan bertujuan untuk mengantarkan jiwa manusia menjadi bersih (dengan lima dayanya) disebut Ikhwan al-Shafa sebagai ‘malaikat dalam potensi'. Karena itu, dalam proses pendidikan, potensi jiwa diaktualisasikan dengan ajaran-ajaran yang diwahyukan dan pengajaran filsafat, sehingga mengaktual pada jiwanya pan-dangan, keyakinan dan pengetahuan yang benar, baik tentang realitas maupun tentang apa yang seharusnya dibiasakan manusia. Ikhwan al-Shafa tidak menafikan syariah/ wahyu, karena dengannya manusia dapat mendekati rahmat Allah melalui ketaatan, dan dengan kearifan/ hikmah dia mendapatkan rahmat Allah melalui pemahaman tanda-tanda kekuasaan dan pemeliharaan-Nya di alam semesta.

Karena itu, pendidikan bagi aliran ini selain menekankan pengembangan potensi jiwa rasionalisme, juga memperhatikan dimensi religiusitas. Proses pendidikan (aktualisasi potensi jiwa) tersebut dilakukan dengan melalui empat tahap: Tahdzib (penanaman akhlak atau penghalusan budi), Tathhir (penyucian jiwa dari kotoran), Tatmim (penyempurnaan jiwa dengan penge-tahuan eksoterik melalui pemahaman ayat kauniyyah), Takmil (penyempurnaan jiwa untuk menerima pengetahuan esoterik/ilham). Pada seluruh tahap tersebut, disajikan kepada peserta didik moral dan pengetahuan sebagai makanan jiwa, keduanya tidak terpisahkan. ${ }^{49}$

\section{MADZHAB ILUM INASIONIS DAN FILSAFATPENDIDIKAN ISLAM SPIRITUALISME-CAHAYA}

Filsafat Islam madzhab Iluminasionis (Isyraqiyyah) digagas oleh Syihabuddin as-Suhrawardi pada abad ke-6 H/ke-12 M di Syria pada saat FilsafatPeripatetik dikritik oleh mutakallimun (para teolog). Secara 
konseptual, aliran ini membangkitkan kembali filsafat perenial (keabadian) yang ada dalam tradisi Yunani Kuno, Persia Kuno, dan Arab-Persia, yang mengutamakan intuisi intelektual (dzauq) tanpa me-ngesampingkan pemikiran diskursif. Jalan mencapai pengetahuan yang benar, menurut tradisi tersebut, ialah membina sikap jiwa zuhud dan penyucian jiwa. Dikembangkan oleh Muh. Syamsuddin as-Syahraruzi dan Qutbuddin asSirazi pada abad ke-7 H/ke-13 M, aliran ini memiliki banyak eksponen dan pengikut beberapa abad berikutnya, khususnya di Persia dan anak benua India.

Tema utama pembahasan Fl lluminasionis adalah konsep 'cahaya'. Cahaya di sini dimaksudkan sebagai pancaran dari rahasia ketuhanan. la merupakan realitas yang tidak memerlukan definisi karena sudah nyata dan jelas dengan sendirinya. la juga merupakan realitas yang menjadikan segala sesuatu tampak, dan substansi yang masuk ke dalam komposisi semua substansi yang lain, baik materiil maupun immateriil. Hakekat segala sesuatu terdiri dari cahaya dan kegelapan, masing-masing dengan peringkatnya. Cahaya Ketuhanan (al-nur al-ilahi) berada pada peringkat tertinggi dalam tatanan realitas, karenanya disebut cahaya dari segala cahaya. la tidak bergerak dari kedudukannya dan kekal dalam keadaan demikian sepanjang waktu, namun secara terus-menerus memancarkan sinarnya ke seluruh jagat raya. Dengan konsep cahayanya, -Suhrawardi menjelaskan penciptaan alam dengan emanasi di mana cahaya memiliki dua bentuk, yaitu cahaya yang terang pada dirinya sendiri dan cahaya yang terang dan menerangi selainnya. Dari Cahaya Pertama (dalam FI Peripatetik dikenal Akal Pertama) beremanasi cahaya-cahaya sekunder, benda-benda langit, dan unsur-unsur fisik yang membentuk alam fisik. ${ }^{50}$

Ada dua ajaran pokok filsafat Isyraqi, yaitu "gradasi esensi" dan "kesadaran diri". Berkaitan dengan gradasi esensi menurut Suhrawardi apa yang disebut dengan eksistensi adalah sesuatu yang ada dalam pikiran dan tidak dalam realitas. Karena itu, realitas sebenarnya adalah esensiesensi yang tidak lain manifestasi "cahaya". ${ }^{51}$ M enurut Suhrawardi, masingmasing cahaya berbeda tingkat entitas penampakannya, tergantung pada tingkat "kedekatannya" dengan Nur al-Anwar (Cahaya Segala Cahaya). Dengan demikian realitas tersusun atas gradasi esensi, yang tidak lain merupakan bentuk-bentuk cahaya mulai dari yang paling lemah sampai ke yang paling kuat. ${ }^{52}$ Adapun ajaran Suhrawardi "kesadaran diri" (idrak al-ana'iyah) berkaitan dengan konsepnya tantang pengetahuan. Dalam 
pandangan Suhrawardi, sebuah pengetahuan yang benar hanya bisa dicapai melalui hubungan langsung (al idhafah al isyraqiyah: hubungan iluminasi) tanpa halangan antara subyek yang mengetahui dengan obyek yang diketahui. Pengetahuan diperoleh tidak hanya dengan kekuatan intuitif, melainkan kekuatan rasio. ${ }^{53}$

Pada hakikat manusia, yaitu cahayanya yang terletak pada jiwa rasional (al-nafs al-natiqah) yang memimpin daya-daya rohani lainnya. Setiap jiwa rasional, betapapun sempurna peringkatnya, senantiasa mencari cahaya. Berbahagialah jiwa rasional apabila ia sedang disinari oleh-Nya atau mendapat pencerahan dari-Nya. Itulah tujuan hidup manusia sekaligus hakekat eksistensinya: memperoleh iluminasi (cahaya pengetahuan) dari Tuhan. Dengan demikian hakekat pendidikan menurut Fl Iluminasionis adalah pengembangan manusia seutuhnya dalam rangka memperoleh iluminasi. Jika pada pendidikan Peripatetik hanya menghasilkan pengetahuan diskursif yang baik, namun belum memadai untuk mencapai tujuan muta'allih (pencari Tuhan) yang ingin tiba pada tingkat pengalaman memperoleh hikmah. Dalam pendidikan spiritualisme-cahaya, tujuan pendidikan, dengan demikian, membentuk manusia utuh, theosopher (alhakim al-ilahi), yang tidak saja menemukan pengetahuan diskursif, namun juga memperoleh pengetahuan teosis (hikmah). Sebagai implikasi, proses pendidikan berlangsung sepanjang proses kehidupan manusia. Dengan kata lain, proses kehidupan sama dengan proses pendidikan. ${ }^{54}$

Tahap-tahap dalam proses pendidikan: 1) mencari pengetahuan, tapi belum mencapai tataran ilmu; 2) pengembangan nalar, diperoleh pengetahuan diskursif; 3) pendisiplinan nafsu dan pensucian jiwa, diperoleh pengetahuan gnosis (hikmah); dan 4) penemuan pengetahuan teosisdiskursif (theosoper). Di atas theosopher ada nabi/imam yang memiliki pengetahuan sempurna tentang metafisika, kosmologi, dan metafisika, dan menjadi teladan kesempurnaan bagi manusia. Dengan demikian, tugas pendidikan ialah mendukung tercapainya iluminasi melalui: 1) penyempurnaan semua daya manusia, baik mental maupun psikologis; 2) keterlibatan elemen rasional dan kejiwaan lainnya dalam semua aspek dan dimensi kehidupan. Dalam proses pencapaian iluminasi, malaikat memainkan peranan sentral (Jibril, jiwa suci, the holy spirit, mursyid). Jadi, pendidikan tidak terpisahkan dari kehidupan spiritual yang berbasis pada pancaran cahaya ilahiyah. 


\section{MADZHAB TEOSOFI-TRANSENDENTAL DAN FILSAFAT PENDIDIKAN ISLAM SPIRITUALISME-SUBSTANTIF}

FI Teosofi Transendental (al-hikmah al-mutaialiyah) dikembangkan oleh Shadr al-Dîn asy-Syîrâzî pada abad ke-11H/ 17M ketika filsafat di dunia Arab tidak berkembang lagi, tetapi terintegrasi ke ilmu kalam dan tasaw uf dalam aspek intelektualnya, sementara di Persia, Irak, Turki dan anak benua India, filsafat (baik Peripatetik maupun Iluminasionis), metafisika, ilmu kalam dan tasawuf semakin mendekat. Filsafat Islam mencapai puncaknya di tangan M ulla Sadra karena berhasil menggabungkan unsur terbaik dari filsafat Peripatetik dan filsafat Iluminasionis, dan kemudian memperkayanya dengan fisafat Wujudiah sufi (khususnya) Ibnu Arabi, sehingga melahirkan ajaran filsafat baru, yakni al-Hikmah al-Muta'alliyah.

M enurut M ulla Sadra, hakekat manusia dapat dilihat pada tujuan atau cita-cita hidupnya, yaitu memperoleh pengetahuan sempurna tentang Tuhan dan kebahagian yang dihasilkan oleh pengetahuan tersebut. Pengetahuan berfungsi mentransformasikan eksistensi manusia. Berdasar prinsip gerak lintas-substansi (al-harakah al-jawhariyah) setiap makhluk selalu dalam proses transformasi; gerak atau perubahan tidak semata dalam bentuk sifat, namun juga dalam bentuk substansi. Dalam kasus manusia, transformasi digambarkan sebagai proses pendakian substansi dari embrio yang masih berupa mineral ke tumbuhan, kemudian dari tumbuhan ke hewan, dari hewan ke manusia, dari manusia ke malaikat, dan akhirnya ke 'dekat Allah' sebagai substansi puncak manusia dalam kehidupan dunia sekaligus tasykik al-wujud dan wahdat al-wujud melandasi bersifat kondusif bagi kehidupan akhiratnya. ${ }^{55}$

Berdasarkan teori Mulla Sadra, gerakan substansial (motion in substance) tidak akan pernah mengubah esensi dari substansi, contohnya seseorang tetap merasa bahwa dirinya adalah orang yang sama (sejak lahir) walaupun dia mengalami perubahan selama hidupnya. ${ }^{56} \mathrm{Hal}$ lain yang dijelaskan dari teori dasar gerakan substansial-nya Sadra adalah mengenai jiwa manusia. Sadra meyakini bahwa jiwa muncul dari tubuh manusia kemudian jiwa mengalami perkembangan dalam cahaya gerakan menuju kesempurnaan, hingga akhirnya menjelma sesuatu yang independen. Inilah hakikat pendidikan sebagai proses berkelanjutan gerak substansi manusia mencapai kualitas tertinggi yaitu jiwa yang dekat dengan Tuhan. ${ }^{57}$ Berdasar prinsip gerak lintas-substansi, setiap makhluk selalu dalam proses transformasi; gerak atau perubahan tidak semata dalam bentuk sifat, 
namun juga dalam bentuk substansi. Menurut Fazlur Rahman "gerak substansi: wujud terus bergerak menuju bentuk-bentuk yang lebih tinggi dan "modus-modus" evolusioner wujud itu berpuncak pada Insan Kamil (M anusia Sempurna). ${ }^{58}$

Mulla Sadra berpendapat bahwa kesadaran diri manusia merupakan bukti adanya esensi non-materialistik dalam manusia yakni jiwa. Jiwa membutuhkan ruang materialistik untuk kemunculan dan ketampilannya. Jiwa yang merupakan elemen kesadaran manusia, bagian internal manusia inilah yang memberikan esensi gerakan dan keadaan eksternal yang mempersiapkan ruang bagi gerakannya. Keduanya diarahkan menuju kesempurnaan dan dikendalikan oleh sebuah jiwa superior. Kesempurnaan jiwa hanya dapat dicapai dengan pendidikan. ${ }^{59}$

Dalam pandangan Mulla Sadra, hakikat pendidikan dapat didapatkan dari konsep gerak substansi (al-harakah al-jauhariyah). Pandangan metafisika pandangan Mulla Sadra tentang pengetahuan. Baginya merupakan gerak substantif (al-harakah al-jauhariyyah) yang berakhir dengan bersatunya intelek manusia dengan intelek transenden dan karenanya, mencapai tingkat wujud yang baru yakni, intelek murni dan tunggal. Gerak evolusioner ini bersifat akumulatif, ia menggambarkan sesuatu yang positif, termasuk tingkat-tingkat wujud yang lebih rendah, dan tidak menghilangkan mereka. Wujud pada tingkat yang lebih rendah merupakan bagian yang terpisah dan saling eksklusif, sedangkan wujud pada tingkat yang lebih tinggi saling inklusif dan menyatu. ${ }^{60}$

Pendidikan dibutuhkan untuk mengisi eksistensi manusia dan kesempurnaan merupakan intervensi jiwa dalam proses penciptaan yang berlangsung terus-menerus. Jiwa seseorang dibangun selama hidupnya dengan ditopang oleh pendidikan yang dicapainya dan tindakan-tindakannya. ${ }^{61}$ Sistem pendidikan Mulla Sadra memandang bahwa perkembangan rasional dan berfikir intuitif sebagai salah satu tujuan penting dari pendidikan. Sistem pendidikan harus dapat menyediakan sarana atau suasana yang membuat siswa memahami semua aspek pengetahuan melalui proses berfikir rasional dan intuitif. 62

Pendidikan sebagai gerak substansi dalam tradisi filsafat Islam, Mulla Sadra, ${ }^{63}$ menyebut di dalam magnup opus-nya al-Asfar al-Arba'ah alAqliyyah (Empat Perjalanan Intelektual). Perjalanan pertama adalah perjalanan makhluk kepada Kebenaran (safar min al-khalq ila al-Haqq); Perjalanan kedua adalah perjalanan bersama Kebenaran di dalam Kebe- 


\begin{tabular}{|c|c|c|c|}
\hline $\begin{array}{l}\text { FILSUF/ } \\
\text { ALIRAN }\end{array}$ & MANUSIA & PENDIDIKAN & $\begin{array}{l}\text { FILSAFAT } \\
\text { PENDIDIKAN }\end{array}$ \\
\hline $\begin{array}{l}\text { Peripatetik: } \\
\text { Ibnu Sina }\end{array}$ & $\begin{array}{l}\text { Manusia Rasional } \\
\text { Filsafat jiwa : (1) Nafsu } \\
\text { Nabati, (2) Nafsu Hewani, } \\
\text { (3) Manusia - yakni jiwa } \\
\text { yang rasional }\end{array}$ & $\begin{array}{l}\text { Aktualisasi dan } \\
\text { penyempurnaan potensi akal } \\
\text { manusia, baik akal } \\
\text { praktisnya maupun akal } \\
\text { teoritisnya. }\end{array}$ & Rasionalisme \\
\hline $\begin{array}{l}\text { Hermetik } \\
\text { Phytagorean: } \\
\text { Ikhwan al-Shafa }\end{array}$ & $\begin{array}{l}\text { Manusia Makhluk } \\
\text { Rasional dan Religius }\end{array}$ & $\begin{array}{l}\text { Aktual isasi potensi-potensi } \\
\text { jiwa (lima unsur: spiritual, } \\
\text { melangit, bercahaya, hidup, } \\
\text { dan berpengetahuan) untuk } \\
\text { menyempurnakan dan } \\
\text { menyiapkannya untuk } \\
\text { kehidupan abadi. }\end{array}$ & $\begin{array}{l}\text { Rasionalisme- } \\
\text { Religius }\end{array}$ \\
\hline $\begin{array}{l}\text { Iluminasi: } \\
\text { Suhrawardi }\end{array}$ & $\begin{array}{l}\text { Manusia Bijaksana: } \\
\text { theosopher (al-hakim al- } \\
\text { ilahi) }\end{array}$ & $\begin{array}{l}\text { Pencerahan Iluminasi untuk } \\
\text { pengembangan manusia } \\
\text { seutuhnya dalam rangka } \\
\text { memperoleh iluminasi } \\
\text { meraih pengetahuan } \\
\text { diskursif dan intuitif tentang } \\
\text { Tuhan. }\end{array}$ & $\begin{array}{l}\text { Spiritualisme- } \\
\text { Cahaya }\end{array}$ \\
\hline $\begin{array}{l}\text { Teosofi } \\
\text { Transenden: } \\
\text { Mulla Sadra }\end{array}$ & $\begin{array}{l}\text { Insan Kamil: jiwa } \\
\text { manusia dekat dengan } \\
\text { Tuhan. }\end{array}$ & $\begin{array}{l}\text { Gerak Substantif (al- Harakah } \\
\text { al-jauhariyah) untuk } \\
\text { membantu kondisi jiwa } \\
\text { manusia menuju kondisi } \\
\text { pengetahuan yang } \\
\text { sempurna (intelektual- } \\
\text { spiritual) memperoleh } \\
\text { pengetahuan sempurna } \\
\text { tentang Tuhan. }\end{array}$ & $\begin{array}{l}\text { Spiritualisme- } \\
\text { Substantif }\end{array}$ \\
\hline
\end{tabular}

naran (safar bi al-Haqq fi al-Haqq); Perjalanan ketiga adalah kebaikan dari perjalanan pertama, sebab perjalanan ini dari Kebenaran menuju makhluk (safar min al-Haqq ila al-khalq); dan Perjalanan keempat adalah kebaikan dari perjalanan kedua, karena perjalanan ini adalah perjalanan bersama Kebenaran di dalam makhluk (safar bi al-Haqq fi al-khalq). ${ }^{64}$

Hakekat manusia dapat dilihat pada tujuan atau cita-cita hidupnya, yaitu memperoleh pengetahuan sempurna tentang Tuhan dan kebahagian yang dihasilkan oleh pengetahuan tersebut (karena dekat dengan Tuhan). Pengetahuan berfungsi mentransformasikan eksistensi manusia. Jadi, hakikat pendidikan adalah membantu pendakian manusia menuju kondisi pengetahuan sempurna yang menjadi tujuan penciptaannya, dan tujuan pendidikan adalah istikmal al-nafs (penyempurnaan manusia dan jiwanya). Teori gerak substansial menurut Rahman adalah sumbangan orisinil Sadra terhadap filsafat Islam. ${ }^{65}$ Ajaran ini adalah uraian lebih lanjut tentang 
"gradasi wujud" yang tidak bersifat statis, tetapi dinamis, bergerak dari eksistensi terendah menuju eksistensi tingkat tinggi. Bagi Sadra, selain ada gerak aksiden, ada gerak yang fundamental yakni gerak substansi. ${ }^{66}$

Berdasarkan penjelasan empat aliran filsafat pendidikan Islam di atas, maka untuk mempermudah dapat dilihat dalam bentuk table.

\section{KESIM PULAN}

Dalam wacana tentang manusia, sejak era filsafat Islam aliran peripatetik (dari al-Kindi sampai Ibnu Rusyd) sampai era filsafat Islam aliran teosofi transendental (Mulla Sadra), wacana tentang hakikat manusia lebih menekankan pada manusia sebagai individu (pengembangan potensi individu manusia). Ibnu Sina dari aliran filsafat Peripatetik, misalnya, memandang hakikat manusia pada jiwanya yang bersifat hierarkis, dimulai dari jiwa yang terendah, yaitu jiwa tumbuhan (al-nafs al-nabatiyyah) yang memiliki tiga daya: daya tumbuh, daya makan, dan daya reproduksi, lalu jiwa binatang (al-nafs al-hayawaniyyah) yang memiliki dua daya: daya gerak dan daya menangkap pengetahuan, dan akhirnya jiwa paling atas, yaitu jiwa manusia, jiwa rasional (al-nafs al-natiqah), yang memiliki dua daya: daya akal praktis dan daya akal teoritis. Jiwa rasional inilah basis filsafat pendidikan Islam aliran "rasionalisme" ala Ibnu Sina yang membedakan manusia dari makhluk lainnya, baik binatang maupun tumbuhan ${ }^{67}$ Sementara itu, M ulla Sadra dari aliran Teosofi Transendental menyempurnakan wacana tentang hakikat manusia dengan jiwa material yang mendahului jiwa tumbuhan, sehingga berada pada hierarki terbawah, dan menambah di atas jiwa rasional dua jiwa lainnya, yaitu jiwa malaikat dan jiwa dekat dengan Allah. Selain menyempurnakan hierarki jiwa manusia, Mulla Sadra menjelaskan bahwa masing-masing kategori pada hierarki jiwa manusia itu merupakan substansi manusia dan jiwa manusia mengalami apa yang disebut gerak lintas-substansi. Artinya substansi jiwa manusia bisa berkembang secara linear menuju kesempurnaannya: dari jiwa binatang ke jiwa manusia, lalu ke jiwa malaikat, dan akhirnya ke jiwa dekat dengan Tuhan.

Dalam artikel ini tidak memasukkan al-Ghazali dan Ibnu Khaldun dalam sebagaimana Jawwad Ridla memasukkan al-Ghazali sebagai aliran Konservatif dan Ibnu Khaldun dimasukkan ke dalam aliran Pragmatis. Ibnu Khaldun lebih bertumpu pada "filsafat sejarah" yang fokus pada isu "peradaban manusia" dan "organisasi sosial, karena itu Ibnu Khaldun lebih 
tepat diposisikan sebagai Sosiolog, daripada seorang Filsuf. 68 Pemikiran Ibnu Khaldun lebih bercorak teologis sebagai "Neo-Hambalisme" bercorak teologi ortodok, daripada filosofis. ${ }^{69} \mathrm{Ada}$ persamaan mendasar antara alGhazali dan Ibnu Khaldun adalah keduanya mereka membuang jauh pretense Neoplatonisme karena secara religious membahayakan manusia dan organisasinya. ${ }^{70}$

Perbedaannya, jika al-Ghazali menjadikan agama sebagai jawaban dari dahaga akan kepastian, sementara Ibnu Khaldun menjadikan Negara sebagai pusat pembicaraannya. Baik Ibnu Khaldun maupun al-Ghazali, menurut penulis tidak tepat diposisikan sebagai Filsuf yang memiliki gagasan filosofis untuk menjelaskan pendidikan. Mereka berdua hanya mempunyai pemikiran tentang pendidikan, tetapi bukan gagasan filosofis. Karena itu, artikel ini menawarkan hanya empat tipologi aliran Filsafat Pendidikan Islam klasik, yakni Rasionalisme (Ibnu Sina), RasionalismeReligius (Ikhwan al-Shafa), Spiritualisme Cahaya (Suhrawardi), dan Spiritualisme-Substantif (Mulla Sadra). Setiap aliran menghargai pemikiran dari tradisi filsafat Yunani Kuno dan/atau tradisi filsafat perenial sejauh tidak bertentangan dengan ajaran pokok Islam.

\section{CATATAN AKHIR}

1 A bdul M unir M ulkhan, "Jejak Filsaf Islam D alam Filsafat Pendidikan Islam: A nalisis Struktural Fungsional Filsafat I slam dalam Buku Filsafat Pendidikan Islam Terbitan Dalam Negeri dan Terjemahan", Laporan Penelitian, (Yogyakarta, LPPKM UIN Sunan Kalijaga, 2013). Lihat Abdul Munir Mulkhan, "Tarbiyah Sebagai IImu Dan Dasar Keilmuan Pendidikan Islam" dalam Imam Machali \& Adhi Setiyawan, ed., Antologi K ependidikan Islam, (Yogyakarta: Jurusan Kependidikan Islam Fak Tarbiyah dan Keguruan U IN Sunan Kalijaga Yogyakarta, 2010), 3-34; A bdul M unir Mulkhan, "Filsafat Tarbiyah Berbasis Kecerdasan M a'rifat", Jurnal Pendidikan Islam Vol II, No. 2, D esember 2013.

2 G eorge R. Knight, Filsafat Pendidikan, terj. O leh M ahmud Arif, (Yogyakarta: Pustaka Pelajar, 2007), 62-206.

3 M uhammad Jawwad Ridha, Tiga A liran U tama Teori Pendidikan Islam (Perfektif Sosiologisfilosofis), terj. (Yogyakarta: PT Tiara Wacana, 2002), 74. Buku ini terjemahan dari "Al-Fikr A I-Tarbawiyy Al-sl-amiyyu; M uqaddimat fi U shul AlIjtima'iyy-ati wal AlH alaniyyat".

4 Dalam memandang fil safat, al-G hazali menggolongkan tiga kelompok filsuf yang hidup di zamannya, yaitu: Fil suf M aterialistic (yang menyangkali adamya Tuhan), Filsuf $N$ aturalistic (mereka yang melakukan riset alam semesta dan seisinya), dan Filsuf Teistik (mereka yang mampu mementahkan argument 
dua aliran di atas). Al-G hazali menyikapi ketiga kelompok di atas dengan langkah-langkah: apabila menyangkut ketuhanan berarti kufur, maka harus ditolak; apabila mengenai penciptaan berarti kategori bid'ah; dan apabila menyangkut filsafat Alam, tinggal menunggu pembuktian semata. Lihat Sobri Washil, Tesis: Filsafat Peripatetik dan K ritik A I-G hazali Terhadapnya, 147-148.

5 Seyyed H ossein Nasr, Islam Tradisi di Tengah K ancah D unia M oden,(Bandung: Penerbit Pustaka, 1994), 133-135.

6 Ali M udhofir, "Pengenalan Filsafat" dalam T im D osen Filsafat IImu Fakultas Filasat U G M Filsafat IImu. (Yogyakarta: Penerbit Liberty Yogyakarta bekerja sama dengan YP Fakultas Fil safat U G M , 1996), 9.

7 George R. Knight, Filsafat Pendidikan, terj. O leh M ahmud Arif, (Yogyakarta: Pustaka Pelajar, 2007), 4-6.

8 O mar M ohammad Al-Toumy AI-Syaibany, Falsafah Pendidikan Islam, terj. oleh H asan Langgulung, (Jakarta: Bulan Bintang, 1979), 28-31.

9 Andik Wahyun Muqoyyidin, "Tipologi Pemikiran Modernis Pendidikan Islam", Jurnal el H ikmah Fakultas Tarbiyah U IN M alang.

10 Ibid.

11 Abdul Munir Mulkhan, "Filsafat Tarbiyah Berbasis Kecerdasan Makrifat", Jurnal Pendidikan Islam:: Volume II, Nomor 2, Desember 2013/ 1435.

12 Zuhairini dkk, Filsafat Pendidikan Islam, (Jakarta: Bumi A ksara, 1992).

13 M. A rifin, Filsafat Pendidikan Islam, (Jakarta: Bumi Aksara, 1996).

14 Abd. Rachman A ssegaf, Filsafat Pendidikan Islam: Paradigma Baru Pendidikan $\mathrm{H}$ adhari Berbasis Integratif-Interkonektif (Jakarta: PT Radjagrafindo Persada, 2011).

15 Perenialismeadalah paham filsafat pendidikan yang muncul pada awal abad XX sebagai reaksi dari gerakan progresivisme di Amerika Serikat. Perenialisme sering juga disebut sebagai aliran filsafat pendidikan yang regresif, yaitu menengok ke belakang; ke zaman Yunani Kuno dan Abad Pertengahan di Eropa. Perenialisme memandang pendidikan lebih pada persiapan untuk hidup daripada kondisi kehidupan nyata. Ibid.

16 Essensialisme dipengaruhi juga oleh filsafat idealisme dan realisme dengan tokoh Plato dan Aristoteles. Essensialisme merupakan aliran filsafat pendidikan yang ingin kembali kepada kebudayaan-kebudayaan lama sebagai warisan sejarah yang telah membuktikan keunggulan dalam kebaikan kebaikan bagi kehidupan manusia. menurut Esensialisme pendidikan harus berpijak pada nilai-nilai yang dapat memiliki kejelasan dan tahan lama yang memberikan kestabilan dan nilai-nilai yang mempunyai tata yang jel as. Tugas sekolah adalah menyiapkan peserta didik supaya berfungsi di masyarakat, sehingga belajar menuntut kedisiplinan. I bid.

17 Pendidikan dalam aliran progresivisme berakar pada pragmatisme. Progresivisme melihat peserta didik sebagai makhluk yang aktif dan kreatif. aliran Progresivisme yang menekankan pada "learning by doing", belajar melalui pengal aman, belajar aktif, belajar secara kelompok serta problem solving. Karena itu, proses belajar berbasis pada siswa (child-centered school) dan kurikulumnya 
mengutamakan aktivitas (activity-centered curriculum). Program sekol ah terefleksi pada kebutuhan dan minat peserta didik, partisi patif dan demokratis. Ibid.

18 Rekonstruksionismeadalah perkembangan dari aliran pendidikan progresif. Pendidikan rekonstruksionisme berangkat dari asumsi bahwa pendidikan progresif belum bisa memperbaiki masyarakat. Rekonstruksionisme memandang bahwa pendidikan adalah rekonstruksi pengalaman hingga mampu menambah makna pengalaman tersebut, serta dapat meningkatkan kemampuan untuk menentukan arah pada pengal aman berikutnya. I bid.

19 O mar M ohammad Al-Toumy Al-Syaibany, Falsafah Pendidikan, 30, 31, 38-39.

20 M uhaimin, Disertasi, "Filsafat Pendidikan Islam di Indonesia (Suatu Kajian Tipologis)", (Yogyakarta, IAIN Sunan Kalijaga, 2002).

21 Secara epistemologi kualitas akal-budi manusia hanya akan memiliki nilai guna bilamana mampu menghargai tradisi dan warisan nilai-nilai budaya Islam dari para pendahulunya, terutama generasi era salaf. Ibid.

22 Secara epistemologi, kualitas akal budi manusia hanya akan memiliki nilai guna bilamana ia mampu menghargai tradisi dan warisan nilai-nilai budaya Islam dari para pendahulunya, yang telah mampu menyelesaikan berbagai persoalan sebagaimana terwujud dal am sejarah (peradaban) I slam. I bid.

23 Secara epistemol ogi, kualitas akal-budi manusia akan berguna dan memenuhi harapan bilamana ia mampu menyesuaikan diri dengan tantangan-tantangan yang ada dan dengan dilandasi oleh iman dan takwanya mampu menyelesaikan problem dan tantangan-tantangan kehidupan yang dihadapinya secara terus menerus sesuai dengan tuntutan perubahan sosial. I bid.

24 Secara epistemo-togi, kualitas akal-budi manusia akan berguna dan memenuhi harapan bilamana ia mampu menghargai tradisi dan warisan nilai-nilai budaya Islam dari para pendahulunya sebagaimana terwujud dalam sejarah (peradaban) Islam, untuk selanjutnya mengembangkannya secara kontekstual dalam merespon tuntutan perkembangan I pteks dan perubahan sosial yang ada.

25 Secara epistemologi, sejarah budaya manusia membuktikan bahwa kreativitas akal-budi manusia telah memperbesar jarak manusia dengan makhluk yang lain. Tuntutan kualitas kehidupan manusia berkembang eksponensial dan menjadi lebih global, sehingga rekonstruksi sosial berkelanjutan atau postparadigmatik perlu dijadikan filsafat ilmu pendidikan. I bid.

$26 \mathrm{Ibid}, 48$.

27 Ibid, 117.

28 Muhammad Jawwad Ridha, Tiga A liran U tama, 5.

29 A bdul Munir Mulkhan, "Filsafat Tarbiyah, 221

30 Sobri Washil, Tesis: Filsafat Peripatetik dan K ritik AI-G hazali Terhadapnya 147148

31 Lihat Seyyed H ossein N asr \& O liver Leaman (ed), Ensiklopedi Tematis Filsafat Islam (buku pertama \& kedua). (Bandung, M izan, 2003). Lihat juga Seyyed H ossein N asr (ed), Ensiklopedi Tematis Spritualitas Islam; M anifestasi. (Bandung: M izan, 2003). Juga Seyyed H ossein N asr (ed), Ensiklopedi Tematis Spritualitas 
Islam;Fondasi (Bandung: Mizan, 2003).

32 Syeed Hosen Nasr, al H ikmah M uta'aliyah M ulla Sadra, 33.

33 Syeed Hosen Nasr, al H ikmah M uta'aliyah M ulla Sadra, 108

34 Hilomorfisme adalah suatu paham yang mempercayai bahwa semua obyek fisik merupakan gabungan dari materi dan bentuk. Istilah ini berasal dari penggabungan dua kata dalam bahasa Yunani, yakni hyl eyang artinya materi dan morphe yang bermakna bentuk atau rupa. Dalam hal ini, materi merupakan potensialitas, sedangkan bentuk adalah aktualitasnya. Ibid., 105.

35 Syeed H osen Nasr, al-H ikmah M uta'aliyah M ulla Sadra, 107

36 Ibid., 112

37 Seyyed H ossein Nasr, Islam Tradisi di Tengah K ancah D unia M oden,(Bandung: Penerbit Pustaka, 1994), 133-135. Lihat, Seyyed H ossein Nasr, Traditional Islam in the M odern World, (N ew York: C olumbia U niversity Press, 1987),149.

38 Seyyed H ossein Nasr (ed), "Teologi, Filsafat, dana Spiritualitas" dalam Seyyeh Hossein Nasr, Ensiklopedi Tematis Spritualitas Islam; M anifestasi. (Bandung: Mizan, 2003), 558.

39 Abd. Rachman Assegaf, Filsafat Pendidikan Islam, 175

40 George R. Knight, Filsafat Pendidikan Isu-su Kontemporer \& Solusi Alternatif, (terj.) oleh M ahmud A rif, (Yogyakarta: I dea-/ Press, 2004), 39.

41 Fu'ad Farid I sma'il dan A bdul $\mathrm{H}$ amid M utawalli, C ara M udah Belajar Filsafat (Barat dan Islam), Terj. Didin Faqihudin, (Jogjakarta: IRC iSod, 2012), 52.

42 Seyyed H ossein Nasr, Traditional Islam,149.

$43 \mathrm{H}$ enry $\mathrm{C}$ orbin, A vicenna and the $\mathrm{V}$ isionary Ratical, diterjemahkan dari bahasa Perancis oleh W illiard R. Trask (Princeton: Princeton U niversity Press, 1988), 350.

44 Seyyed H ossein Nasr, Traditional Islam,151.

45 Seyyed H ossein Nasr, Traditional Islam,149.

46 Seyed H ossein Nasr \& O liver Leaman (ed), Ensiklopedi Tematis Filsafat Islam, 277.

47 M uhammad Jawwad Ridha, Tiga A liran U tama, 82.

48 Seyyed H ossein Nasr, Traditional Islam,156.

49 Ibid., 157.

50 Seyyed H ossein Nasr, Traditional Islam,156.

51 A rmahedi M ahzar, 'Pengantar' dalam Faz ur Rahman, Filsafat Shadra, xv.

52 Syeed H ossein Nasr, Tiga Pemikir Islam, 88-89.

53 Seyyed H ossein Nasr \& O liver Leaman (ed), Ensiklopedi Tematis Filsafat Islam, 36.

54 Seyyed H ossein Nasr, Traditional Islam,157.

55 Syeed Hossein Nasr, Traditional Islam,158.

56 Ibid., 10.

57 Tahereh Javidi Kalateh Jafarabadi, M ullah Sadra's Idea about "existence" and "motion in substance" and its educational implications, Ferdowsi U niversity of Mashhad, 11.

58 Fazlur Rahman, Filsafat Sadra, 17. 
59 Tahereh Javidi, M ullah Sadra's Idea, 12.

60 Fazlur Rahman, Filsafat Sadra, (Bandung: Penerbit Pustaka. 2000), 310.

61 Ibid., 13.

62 Ibid., 14.

63 Syaifan Nur, Filsafat Wujud M ulla Sadra (Yogyakarta: Pustaka Pelajar, 2002), 1.

64 Syeed Hosen Nasr, al-H ikmah M uta'aliyah M ulla Sadra, 108.

65 Fazlur Rahman, Filsafat Sadra, 48

66 Ibid, 127.

67 'A bd al-R ahman al-N aqib, "A vicenna" dalam Prospects: the $Q$ uarterly Review of C omparative E ducation, (Paris, U NESC O : International Bureau of Education, 2000), vol. XXIII, no. 1/ 2: 54-55.

68 Seyyed H ossein Nasr \& Oliver Leaman (ed), Ensiklopedi Tematis,446.

69 Jika dikaitakn dengan kontroversi I bnu Rusy dan AI-G hazali tentangfilsafat, maka Ibnu Khaldun lebih berpihak pada AI-G hazali, I bid, 451-453.

70 Ibid., 454.

\section{DAFTAR PUSTAKA}

A bd al-R ahman al-N aqib,2000. "Avicenna" dalam Prospects: the Q uarterly Review of C omparative Education, (Paris, U NESC O : International Bureau of Education), vol. XXIII, no. 1/2.

Abd. R achman Assegaf, 2011. Filsafat Pendidikan Islam: Paradigma Baru Pendidikan $\mathrm{H}$ adhari Berbasis Integratif- nterkonektif Jakarta: PT Radjagrafin do Persada.

A bdul M unir Mulkhan, 2013. "Filsafat Tarbiyah Berbasis Kecerdasan Ma'rifat", Jurnal Pendidikan Islam Vol II, No. 2.

Abdul Munir Mulkhan, 2013."Jejak Filsaf Islam Dalam Filsafat Pendidikan IsIam: Analisis Struktural Fungsional Filsafat Islam dalam Buku Filsafat Pendidikan Islam Terbitan Dalam Negeri dan Terjemahan", Laporan Penelitian, Yogyakarta, LPPKM U IN Sunan Kalijaga.

Ali M udhofir, 1996."Pengenalan Filsafat" dalam Tim D osen Filsafat IImu Fakultas Filasat U G M Filsafat IImu. Yogyakarta: Penerbit Liberty Yogyakarta bekerja sama dengan YP Fakultas Filsafat U G M .

Andik Wahyun M uqoyyidin, "Tipologi Pemikiran M odernis Pendidikan Islam", Jurnal el H ikmah Fakultas Tarbiyah U IN M alang.

C. A. Q adir, 1990. Philosophy and Science in the Islamic World, L ondon: Routledge. Fazur Rahman, 2000. Filsafat Sadra, Bandung: Penerbit Pustaka.

Fu'ad Farid Isma'il dan A bdul H amid M utawalli, 2012.C ara M udah B elajar Filsafat (Barat dan Islam), Terj. Didin Faqihudin, Jogjakarta: IRC iSod.

G eorge R. 2007. Knight, Filsafat Pendidikan, terj. O leh M ahmud Arif, Yogyakarta: Pustaka Pelajar.

H ussein Shahab, 2003. "Filsafat Wujud", Jurnal al.H uda, Vol. 3, No. 1.

M. A rifin,1996.Filsafat Pendidikan Islam, Jakarta: Bumi A ksara.

Muhaimin, 2002. Disertasi, "Filsafat Pendidikan Islam di Indonesia(Suatu Kajian Tipologis)",Yogyakarta, IAIN Sunan Kalijaga. 
Muhammad Jawwad Ridha, 2002. Tiga A liran U tama Teori Pendidikan Islam (Persfektif Sosiologisfilosofis), terj. Yogyakarta: PT Tiara Wacana.

O mar M ohammad Al-Toumy Al-Syaibany, 1979 Falsafah Pendidikan Islam, terj. oleh H asan Langgulung, Jakarta: Bulan Bintang.

Seyyed H ossein Nasr \& Oliver Leaman (ed), 2003. Ensiklopedi Tematis Filsafat Islam (buku pertama \& kedua). Bandung, Mizan.

Seyyed Hossein Nasr (ed), 2003. Ensiklopedi Tematis Spritualitas Islam;Fondasi Bandung: Mizan

Seyyed H ossein Nasr, 2017. A IH ikmah al-M uta'aliyah M ulla Sadra,(Jakarta: Sadra Press.

Seyyed H ossein Nasr, 1994. I slam Tradisi di Tengah K ancah D unia M odern,(Bandung: Penerbit Pustaka.

Seyyed Hossein Nasr, 1987. Traditional Islam in the M odern World, (New York: Columbia U niversity Press.

Sobri Washil, Tesis, "Filsafat Peripatetik dan Kritik AI-G hazali Terhadapnya", (Jakarta: UI).

Syaifan Nur, 2002 Filsafat Wujud M ulla Sadra Yogyakarta: Pustaka Pelajar.

Tahereh Javidi Kalateh Jafarabadi, M ullah Sadra's I dea about "existence" and "motion in substance" and itseducational implications, Ferdowsi U niversity of M ashhad. 